\title{
Self-Identity Among African American Women
}

Author: Andrina J. Jackson

Faculty Mentor: Beverly Davenport, Department of Anthropology, College of Public Affairs and Community Service, University of North Texas

Department and College Affiliation: Department of Anthropology and Department of

Sociology, College of Public Affairs and Community Service, University of North Texas 


\section{Bio:}

Andrina J. Jackson is a founding member of Gamma Sigma Sigma National Service Sorority at the University of North Texas. She plans to continue in graduate school in sociology. Presently, she is focusing on the critical experiences of young African American women and the influences their social environments have on the development of their individual identities. 


\begin{abstract}
:
The objective of this research project was to explore the influence of their social environments on young African American women and the development of their identities. This study shows the results of five semi-structured interviews with African American women between ages 18 and 26 and was designed to collect their life histories in order to better understand influences their present environments have on their life choices and their ability to obtain upward mobility throughout society’s class system.
\end{abstract}




\section{Introduction}

Due to economic, social, political, and environmental challenges, many African American communities are faced with adversities that are rarely found in other racial communities. Racial segregation continues to exist in many areas of our society, including in the housing, educational, and employment sectors (Massey \& Denton, 1993). Presently the African American community is plagued with segregated neighborhoods, unequal educational systems, and an abundance of negative media coverage, inadequate law enforcement protection, singleparent households, and a major deficiency in economic resources. Furthermore, due to the lack of urgency to solve these systematic problems, Black America continues to suffer from structural violence. According to anthropologist Philippe Bourgois, structural violence refers “to the political-economic organization of society that imposes conditions of physical and emotional distress, from high morbidity and mortality rates to poverty and abusive working conditions” (Bourgois, 2001, p. 3).

Hill Collins (2000, p. 22) wrote, “U.S. Black women constitute an oppressed group.” Unsurprisingly, African American women tend to be one of the groups that find themselves overlooked and lacking in resources. Yet, despite these obstacles, many do manage to obtain upward mobility, form a strong sense of self, and become successful in the eyes of the dominant population. "Overall, U.S. Black women as a group live in a different world from that of people who are not Black and female,” Hill Collins said (2000, p. 23). Unfortunately, only limited research has been focused on young African American women's self-identity in relation to their social environment; thus the objective of this research study is to explore some existing concepts, theories, and ideologies concerning African American women and to attempt to determine what aspects of self-identity are shaped by an individual's social environment. 
Previous research has placed emphasis on environmental factors and the impact these have on the Black "middle-class way of life” (Pattillo-McCoy, 1999) and “decent families” (Anderson, 1999). I hypothesize that an individual's social environment may be a determining factor in the formation of an individual's self-identity, and that one's self-identity may then become a determinant in one’s general success. In this paper, I will first be exploring the scholarly works by some of the major contributors to the analysis of Black lives and Black communities in the United States. I researched Patricia Hill-Collins’ Black Feminist Thought (2000); Mary Pattillo-McCoy’s Black Picket Fences (1999); and Elijah Anderson’s Code of the Streets (1999) to gain better insight into the relationships among social environments, selfidentity, and success. Then I will report on my own interview data.

\section{Literature Review}

“Self- definition has been essential to U.S. Black women’s survival...By advancing Black women's empowerment through self-definition, these safe spaces help Black women resist the dominant ideology promulgated not only outside Black civil society but within AfricanAmerican institutions” (Hill Collins, 2000, pp. 98, 101). Self-definitions are the ways in which Black women define themselves through their own perceptions and not the perceptions of society. By doing this they help to reform ideologies, environments, and social institutions that accept the Black women's perceptions of themselves and these places of acceptance become safe spaces “where Black women speak freely” (Hill Collins, 2000, p. 100). Hill Collins notions about self-definition in Black Feminist Thought give some insight into the concerns, ideology, and overall significance of the construction of Black women's identity. Hill Collins claims that through this awareness of one's self one will eventually gain empowerment, which can be seen as a type of success. To Hill Collins, empowerment is the key to allowing one to understand the difference between women's “acts of resistance” such as choosing to be silent in contrast to 
women rendering themselves submissive. Silence is used as a coping mechanism for many of the African American women presented through Hill Collins’ work. For these Black women, silence is used as a way to keep them safe in threatening situations. Also, at times, it could be used to ease the tension of being a Black minority in a White majority society and being a woman in a male-dominated social structure.

In contrast, silence and/or silencing, according to Signithia Fordham in her article, “Those Loud Black Girls,” are the “efforts to suppress” gender diversity, cultural awareness, and sexuality (Fordham, 2000). Currently, White middle-class Americans are accepted as the norm in American society. By accepting this idea of social normality, many women of color are “compelled to silence” and stripped of their own self-identity (Fordham, 2000). When Fordham’s research subjects, high-achieving students in Washington, D.C., “got loud,” Fordham interpreted their noise as a rejection to such suppressions.

Both Hill Collins and Fordham agree that "silence” plays a role in the formation of Black women’s self-identity and reveal critical factors such as Black women’s placement in society, society’s perception of Black women, and the historical image of the Black woman. According to Hill Collins, these definitions of "Black womanhood advanced by Whites as well as the discriminatory social practices that these controlling images supported” help to create expectations and a socially accepted “ideal” Black woman who defines her position in U.S. society (Hill Collins, 2000, p. 10). Thus, “Black women’s lives are a series of negotiations that aim to reconcile the contradictions separating our own internally defined images of self as African-American women with our objectification as the Other” (Hill Collins, 2000, p. 99). I move now to a brief consideration of how the roles of families and peers are conceptualized. “The mother/daughter relationship is one fundamental relationship among Black 
women. Countless Black mothers have empowered their daughters by passing on the everyday knowledge essential to survival as African-American women” (Joseph, 1981, cited in Hill Collins, 2000). On the other hand, some Black mothers have failed to do this and the lack of selfawareness they may have tends to trickle down to the next generation.

Elijah Anderson's Code of the Street examines the influences of the social environment on "self-image" and the extent to which social environments determine the outcome of one's success or ability to "determine the way the child will ultimately turn out" (Anderson, 1999, p. 68). Through his work, Anderson illustrates how the "street serves as a mediating influence under which children may come to reconsider and rearrange their personal orientations” (Anderson, 1999, p. 67). Furthermore, he gives keen insight into the possibility that a relationship does exist between the environment one grows up in and one's self-identity.

For instance, Anderson explains, “Children from even the most decent homes must come to terms with the various influences of the street" (Anderson, 1999, p. 67). Later he demonstrates ways in which a child's social environment can impact their chances of obtaining success as time progresses: “The neighborhood and the surrounding environmental influences, including available social and economic opportunities and how the child adapts to this environment, are key” (Anderson, 1999, p. 68). Anderson’s definition of social environments relies on the people who are actively living within these shared environments, the places seen in these shared environments, and the events taking place in these shared environments.

Mary Pattillo-McCoy, author of Black Picket Fences, acknowledges the increasing concerns regarding Black middle-class family life in Chicago (1999). She explores political, social, and spatial contexts that affect Black Americans in urban settings and some of the reasons behind the decreasing number of Black middle-class families living in cities. Pattillo-McCoy 
believes that there are "important connections between public policy, racial stratification, economic change, and middle-class culture” (Pattillo-McCoy, 1999). Also, Pattillo-McCoy provides more insight about the influence of mixed class social environments on Black middleclass families.

My questions about the roles, influences, and results of self-identity, social environment, and success through their works have led me to do some preliminary work of my own that uses the work of Anderson, Fordham, Hill Collins, and Pattillo-McCoy as guides to understand the Black female population in depth when examining their similarities and differences in their social environments, self-identity, class system, chances at obtaining upward mobility, social status, education system, aspirations, and family structure.

\section{Research Design}

The purpose of this study was to explore the relationship between self-identity and critical life experiences of young African American women and examine the influences their present environments have on their life choices and their ability to obtain upward mobility throughout society's class system.

I interviewed 5 women between the ages of 18 and 26 who primarily identified themselves as being African American. Open-ended, semi-structured interviews were used to collect their life histories. The research questions covered their experiences that took place in critical points in their life, such as:

- in their childhood

- in their school days, from kindergarten through college

- in their family units.

All interviews were transcribed and coded to establish patterns. These patterns focused 
on five factors: social and physical environment, social constructionism, Black as a label/lifestyle, the family unit, and ambitions as shaped by critical life experiences. The majority of the study population live in various neighborhoods in the Dallas, Texas, area. Dallas is the 9th largest city in the United States and has well over 1 million people living there, and southern parts of Dallas are predominately populated by African Americans and have high rates of poverty and crime. Most of the women came from single-parent households; some of the women were themselves also single parents. All came from similar middle-class backgrounds. “Middle class” is a notoriously elusive category based on a combination of socioeconomic factors (mostly income, occupation, and education) and normative judgments (ranging from where people live, to what churches or clubs they belong to, to whether they plant flowers in their gardens) (Pattillo-McCoy, 1999, p. 13). This study population was middle class due to their median income level, level of education attainment, and the neighborhoods they live in that can all be associated with being typically middle class. Participants all graduated from high school and have some higher educational background including college or technical school. All participants also had a mixed racial heritage, but identified primarily as African American or Black. Their unique demographics allowed me to show similarities and differences within the African-American community.

\section{Findings}

First, I will examine the sociological theory, the looking-glass self, which is a theory that explains how individual's identities are determined by the conceptions of others within society. Next, I will look at the ways in which the research participants sought to gain upward mobility through monetary gain. Then I will measure their understood success through the lenses of their individual aspirations. Moreover, I will examine their networks of support and family structures 
to gain a better understanding about the overall role of one's social environment. Finally, I will examine how the participant conceptualizes "Black or being Black," honing in on the ways in which these ideas are socially constructed.

\section{Looking-Glass Self}

The sociological theory, the looking-glass self, can be used by one to gain identity through the perceptions of themselves by society (McIntyre, 2007. Tragically, many African American women's self-identities have been negatively affected to some extent because the society that reflects their "selves" is White. This is brilliantly shown in the extended article, "Those Loud Black Girls.” In this article, Signithia Fordham focused on African American female students and the methods they use to construct and portray their gender roles and identities in an academia setting. Moreover, the causes and effects, acceptance of marginalized images, and challenges faced by African American female students in the classroom were intensely explored by Fordham and through this population Fordham is able to examine the stratification system utilized in the United States. Fordham learns that these African American female students are more likely to learn their appropriate gender roles through their perceptions of what is accepted in White American society. By doing this they deny themselves the opportunity of being able to define themselves and choose which roles they want to have in order to "fit" into academia.

When asking one participant of mixed heritage what race she considers herself to be, she quickly responded, “I’m Black! I mean my daddy is more Black so...” (Participant \#5). To her she identified as being more Black because in New Orleans, Louisiana, where her father is from, a person of his dark skin complexion would be considered Black, thus she feels as if society’s perception of him has also become society's perception of her although she lives in a completely different state. In this case the sociological theory, the looking-glass self, presents itself to be of 
true nature because one has stopped "self-defining” themselves and has allowed society to do the defining for them.

\section{Obtaining Upward Mobility through Riches}

Many of the women who participated in this project express a desire to gain upward mobility; however, the only options that seemed available to them was by moving up the "social ladder” through monetary gain. When asking one participant about her goals for the next 15 years, she repeatedly emphasized the importance of having a financially stable environment for her family. As a child, she wondered why they never seemed to have money. She states, "Just growing up we never really had money... I would be like Mommy, why don’t we have any money?” (Participant \#4). However, as an adult she wants something totally different for her child. She describes money as being a "safety net" that would help ensure and build her a more stable environment that she was not able to have.

A similar childhood experience was given by a different participant when asked if she thought coming from a single-parent home affected her outlook of life. With assurance she stated it did "a lot, because I watched my mama struggle. At one point she was working like three jobs

and we barely saw her. She pretty much was nonstop” (Participant \#2). Thus when asked later on if she believed money is needed in order for her to achieve her goals, she said, "Yes, you need money for everything except to pretty much breath now” (Participant \#2).

Both research participants fully understand the struggles of not having money and not being able to leave your current situation or environment because you lack the resources. To them, money brings about hope and puts an end to their fears about having to struggle like their mothers. Although both of the participants honor their mothers for the sacrifices they gave, they both are fully aware that if they want to gain upward mobility and have a stable environment in 
their worlds, then they must be earning money.

Monetary gain does not necessarily guarantee a rise in one's class status; however, it does provide one with the opportunity to live in a more comfortable and stable environment. The reality is that "middle-class African Americans run a greater risk of downward mobility than Whites, who generally start off as more solidly middle class in the first place” (Duncan, Smeeding, \& Rogers, 1993; Yeung \& Hofferth, 1998).

\section{Aspirations}

Success is measured very differently in certain cultures, ethnic groups, social classes, communities, and social institutions. For example, the success one gains from graduating from high school may be measured differently for an individual from a working-class family versus an individual from a middle-class family. The responses of my research participants helped me to see a connection between the way they understood "success" and their future aspirations. Aspirations are not measured but acknowledged, thus the general "success" of my research participants’ will be examined through their aspirations. Although I did not quantitatively measure aspirations, I made a judgment about the likelihood of the research participants achieving their aspirations based on their current situations. I have no intention in imposing judgments on the willingness of my research participants to succeed but am only here to show the vital linkage between success and aspirations.

When asked about their goals in the next 1 to 5 years, many of the participants answered by telling me what they aspire to become one day, some with the hopes of helping others and some with the goal of helping themselves gain a better life.

A 20--old college student from Atlanta, Georgia, claimed, when asked about her goal for next year, that she "hope[s] to be in law school" (Participant \#1). It seems as if she is on the right 
path to fulfilling her goal. She is in an environment that encourages expansion of knowledge and praises success. She also has a positive support system and has surrounded herself with college friends who are also pursuing graduate-level studies. Thus, the likelihood for her to graduate from undergraduate school and pursue a law degree is very likely in this situation.

On the other hand, when another participant was asked about her future goals in the next 5 years, what she aspired to do in the future did not seem likely given her current situation. A 21year-old, first-generation college student dropout expressed that she "want[ed] to be a teacher, a high school one teaching African American Studies" (Participant \#2). This is where the "ideal” reality and actual actuality clash. Her ideal is that eventually she will become a high school teacher but in actuality, she dropped out of the path that would have gotten her there in order to join the workforce. By doing this, she minimized her chances for being able to become a teacher.

This desire of wanting to attend college but not actually attending college is a very common one in the Black community. Pattillo-McCoy reveals the desire for Groveland residents to go to college and the reasons why they did not, but she ultimately reveals that the lack of college attendance by middle-class Blacks is due to financial security. Pattillo-McCoy does this by saying that "there is often as much 'college talk' as there is college attendance in Groveland. Youth often talk about college-their plans, the costs, their stints in and out-even when they are not enrolled. Financial hardships are the primary reasons for delay” (Pattillo-McCoy, 1999, p. 63).

The lifestyle describing the typical traditional college student includes work and school. Many of these students realize that they have to work in order to pay to attend school, yet finishing school is the only way to improve their situation. "I'm going to finish school in like a year or maybe a year and a half. I like the job I'm at now. It's a marketing job, but you can move 
your way up. I'm going to move up,” one participant said (Participant \#3). Early on she realizes that she likes the job that she is presently at but not the position that she has there. She also realizes that once she completes school then she will have the option of moving up the job ladder.

A 21-year-old, single-parent mother from Singing Hills, Texas, stated that she had interest in becoming "a pharmacist or teaching pharmacy at a school somewhere” but mainly “somewhere making a lot of money” (Participant \#4). Here money seems to be the driving force in being the reason why she wants to become a pharmacist. To her, pharmacists are the people making the most money and they are the ones who can provide her family with a better life.

A recent 21-year-old graduate from a Dallas, Texas, cosmetology school assertively stated, "I want to have at least about 2 shops in the next 5 years. At least 2. I want to have a shop in Detroit. The Hair National” (Participant \#5). With her state-approved cosmetology license, she is a step closer to being able to open her own beauty shops. She has decided to use her talent of being able to "do hair" and capitalize from it.

Many of the participants aspired to become things that their experiences had led them to. For instance, one of the participants did not have any interest in the field that she desired to become a professional in, but because it offered her a stable environment she decided that that would be in the best interest for her family while another one knew she had a talent so her way to provide was by doing what she was naturally good at.

\section{Changing Family Units}

"In general, everything the imagined traditional family ideal is thought to be, AfricanAmerican families are not,” Hill Collins (2000, p. 47) said. African American communities are seeing a shocking decrease in dual-parent households and an increase in single-parent homes. 
The majority of my research participants came from either a single-parent home or an extended family kinship, usually formed through their grandmothers.

“The existence of the institutionalized grandmother role is a major feature of Black family life,” Anderson, 1999, p. 208) wrote. “Among inner-city Blacks, because of strong tradition, it appears to be a mandatory role with established rights, obligations, and duties, and those that refuse it may be judged by many in the local Black community as having abdicated a vital responsibility. In many Black communities, a grandmother is more than just being a part of the extended family. To some extent, a grandmother is the one person in which many individuals gain a better sense of who they are from.

When asked to describe her experiences with living next door to her grandmother, one participant replied:

I really enjoyed the times with my grandmother. I probably stayed at her house most of the time. She was right there so I would go shopping with her and stuff and we would probably take the bus and go uptown. That's probably were I get my shopping from now. I'm addicted to shopping, but we had a really fun time before I went to school. My grandmother is a character. So it's my mom's mom and she would identify herself as Mexican as I would say because her father was. But he had died very early in her life and I think that is why she never learned any Spanish. And I think that weighed heavily on her and that is why she is not very connected to her roots like she might have hoped to be, but she liked to cook and liked to play cards. She was a gambler. Gambler. I learned to play cards at like three. I knew all the games and stuff and I could really play because she taught me to play cards. I was drinking coffee at like four years old as a kid. She would like baby-sit other people’s kids and stuff but they weren’t around my age. Strange now 
that I think about it, how I grew up. (Participant \#1)

\section{Becoming More than Color}

"Middle-class Blacks are conscious of their Blackness, seem to feel an obligation to the race due to their more 'privileged' position, and express a strong sense of group solidarity," according to Pattillo-McCoy (1999, p. 19).

You know, I would consider myself to be Black but I am a mix of a lot of stuff so maybe “Other.” I like to check off “Other” when they ask me. I don’t know what Black means. Black is a color. But for some people Black is a lifestyle but I don’t really be with people who think Black is a lifestyle. In high school they had Black, African American, African, and whatever else you wanted to identify as and who you think you are and I didn’t think Black was a color, and I didn't think White was a color. What does that mean? So I didn’t really know what to say I was. (Participant \#1)

She clearly refuses to be “boxed in” by others’ perception of her and as a result she has allowed herself to define herself as an individual.

Ideas of what it means to be Black and growing up Black seem to overshadow the similarities and differences within the African American community. African Americans of various social classes have had to struggle with ethnicity labels that the dominant population and the African American community continue to create. This leads to the acceptance of some and the exclusion of others, eventually leads to the splitting and further separation of the African American community in general.

New Orleans, Louisiana, is a city richly filled with a mix of residents from different races and ethnicities. New Orleans’ native, Research Participant \#1, comes from a very mixed family 
including Mexican, Native American, Creole, and African American ancestry. In addition, Research Participant \#1 went to Catholic school instead of public school and lived in a wellestablished, middle-class neighborhood in a dual-parent household. Simply put, Research Participant \#1 would be considered a part of the “decent families” (Anderson, 1999, p. 37).

“Almost everyone residing in poor inner-city neighborhoods is struggling financially and therefore feels a certain distance from the rest of America, but there are degrees of alienation, captured by the terms 'decent' and 'street' or 'ghetto,' suggesting social types,” said Anderson (1999, p. 35). Anderson conceptualizes the differences between being a part of the In group or the Out group. Here he uses the labels “decent” and "street” and compares the "degrees of alienation” each label suffers from society, rather than the larger American society or the smaller society that the individual lives in. By Research Participant \#1 being a part of the “decent” social category, she faces the possibility of being excluded by her own society that may be more typically "street” in nature but accepted by the larger American society that exhort all that is “decent.”

\section{Discussion and Personal Reflection}

To some extent, individuals tend to learn the behaviors, traditions, languages, aspirations, and self-images that are accepted by their communities and create their own identity from these ideals. More research needs to be conducted about the relationship between one’s self-identity and one's social environment. This could be done through grasping a better understanding about the lifestyles, challenges, roles, and positions of Black women in America’s larger social context. I am particularly interested in pursuing the silence/silencing/silenced metaphor and its meaning for young African American women.

Being a member of the African American community myself has allowed me to witness 
firsthand some of the issues that impede the advancement of African American communities. The willingness to gain upward mobility does not seem to be an option for many individuals in the African American community, thus the urgent need for research to take place in order to improve African American communities is crucial. This targeted minority population have been victims of racial and discriminatory acts that has caused a negative ripple effect in terms of their social, political, and economic achievements and standings in society. With the strengthening of the separation of class divisions, the African American community is threatening to lose its entire cultural identity. This is a major dilemma! To me, cultural identity plays a key role in helping to form one's individual identity; hence also providing them with the understanding of their role in society. The loss of cultural identity ultimately results in the diminishing of selfidentity, thus making it more challenging for one to find her way through life. Moreover, I believe that the absence of self-awareness can lead to problems such as not being able to establish gender performance roles throughout the family or community, lower self-esteem, and causes the increased likelihood of being conformed into the dominate population. In my opinion, these are appalling outcomes because they devalue the entire African American race. For instance, the article The Bleaching Syndrome: African Americans Response to Cultural Domination Vis-a-Vis Skin Color by Ronald Hall focuses on the effects of losing one's identity through the act of dominant Anglo conformity through the bleaching of one's skin. Hall states that the bleaching syndrome is the "process they use to perceive, understand, and compare simultaneously the values, attitudes, and behavior of the larger societal system with those of the immediate family and community system... at one end is identity for African Americans as defined by the dominant culture-perhaps less valued” (Hall, 1995, p. 175).

I plan to do future research based on some of the same ideas as seen in this project. It 
would be more beneficial to me to be able to collect the oral life histories of older African Americans and other minority, underrepresented populations. It would be interesting to see some universal challenges faced by other groups of people who have similar political and historical backgrounds in the United States and see how the relationship between identity and social environments relate and differ from each other. 


\section{References}

Anderson, E. (1999). Code of the street. New York: W.W. Norton \& Company.

Bourgois, P. (2001). The power of violence in war and peace: Post-Cold War lessons from El Salvador. Ethnography, 2(1), 5-34.

Duncan, G., Smeeding, T., and Rogers, W. (1993). W(h)ither the Black middle class? A dynamic view. In D.B. Papadimitriou and E.N. Wolff (Eds.), Poverty and Prosperity in the USA in the later twentieth century (pp. 240-71). New York: Saint Martin’s Press.

Hill Collins, P. (2000). Black feminist thought: Knowledge, consciousness, and the politics of empowerment. New York: Routledge.

Massey, D. S., and Denton, N. A. (1993). American apartheid: Segregation and the making of the underclass. Cambridge, Mass.: Harvard University Press.

Fordham, S. (2000). "Those loud Black girls": (Black) women, silence, and gender "passing” in the academy. In B. A. Levinson, and K. M. Borman (Eds.), 2000, Schooling the symbolic animal: Social and cultural dimensions of education (pp. 327-343). Lanham, Md.: Rowman \& Littlefield Publishers.

Hall, R. (1995). The bleaching syndrome: African Americans response to cultural domination vis-a-vis skin color. Journal of Black Studies, 26, 172-184.

McIntyre, L. (2007). The practical skeptic: Core concepts in sociology. Mountain View, CA: Mayfield.

Pattillo-McCoy, M. (1999). Black picket fences: Privilege and peril among the Black middle class. Chicago: The University of Chicago Press.

Yeung, W. J. \& Hofferth, S. 1998. Family adaptations to income and job loss in the U.S.", Journal of Family and Economic Issues, Vol. 19(3): 255-283. 